\title{
上顎骨内に発生した腺癌（NOS）の 1 例
}

\author{
吉澤邦夫・田中彰・高桜大輔 \\ 能崎晋一・中川清昌・山本悦秀
}

\section{A case of adenocarcinoma (NOS) arising in the maxilla}

\author{
YOSHIZAWA Kunio - TANAKA Akira - TAKAZAKURA Daisuke \\ NOZAKI Shinichi · NAKAGAWA Kiyomasa · YAMAMOTO Etsuhide
}

\begin{abstract}
Salivary gland tumors of the maxilla are rare. A case of adenocarcinoma, NOS in the maxilla is reported in this paper. A 67-year-old woman had been aware of a mass in the hard palate and tenderness at the base of ala nasi for a few months. The lesion was clinically suspected to be a benign maxillary tumor and was excised under general anesthesia. The mass was pathologically diagnosed as adenocarcinoma, NOS. It was suggested that adenocarcinoma, NOS arose from the minor salivary gland and was entrapped in the maxilla.
\end{abstract}

Key words: adenocarcinoma, NOS (腺癌 (NOS)), maxilla（上顎骨）

緒

言

顎骨内に生じる唾液腺悪性腫瘍は，比較的まれである ${ }^{1)}$. その内，腺癌（not otherwise specified, NOS）は, 唾液腺の 悪性上皮性腫痬に分類されるが，いずれの悪性上皮性腫瘍 のカテゴリーにも属さない腺癌とされており ${ }^{2)}$ ，これまで 本腫瘍の顎骨における報告例は下顎骨で散見されるもの の，上顎骨での報告は見当たらない. 今回，われわれは上 顎骨内に発生した腺癌（NOS）の1例を経験したので，文 献的考察を加えて報告する.

\section{症例}

患 者： 67 歳, 女性.

初 診：2003 年 3 月回日.

主 訴： $1+3$ 口蓋側菊肉部の腫脹.

既往歴・家族歴：特記事項なし.

現病歴： 2002 年 12 月頃に近医菊科を通院中に $\lfloor 2$ 口蓋 側柬肉部の無痛性腫脹が出現し, 徐々に増大を認めた. 2003 年 2 月頃より左側鼻翼基部の軽度圧痛も伴うように なった．腫脹の精查希望にて同医を再診したところ， $\lfloor 2$ 原 因の柬根囊胞を疑われ，根管治療を施行されたが，症状の 改善を認めなかった。 その後，穿刺して内容液が認められ なかったことから，充実性病变を疑われ，精査・加療を目 的に当院を紹介され，2003 年 3 月日日当科初診となった.

現 症：

全身所見；体格は中等度で, 栄養状態は良好.

金沢大学大学院医学系研究科がん医科学専攻がん細胞学講座 細胞浸潤学分野 (菌科口腔外科学)

(主任：山本悦秀教授)

Oral \& Maxillofacial Surgery, Department of Cell \& Tissue Biology, Division of Cancer Medicine, Kanazawa University Graduate School of Medical Science (Chief: Prof. YAMAMOTO Etsuhide)

受付日：2004 年 8 月 20 日

採択日：2005年 6 月 28 日
口腔外所見 ; 左側鼻翼基部の軽度圧痛を認めるも，ほかに 異常所見はなく, 当該部位の知覚・運動麻痺も認めなかった。

口腔内所見 $; \underline{1}+3$ 口蓋側藏肉から硬口蓋部にかけて 境界明瞭, 弾性硬，丘状の腫脹を認めた，腫脹部は正常粘 膜で被覆されていた（写真 1)。这は失活して抢り，打診 痛を認めたが, 動摇や自発痛は認めなかった。

$\mathrm{X}$ 線所見：初診時，パノラマX $\mathrm{X}$ 線写真では, $\underline{2+3}$ 部に 境界明瞭な骨透過像を認めた (写真 $2 \mathrm{~A}$ )。4月日日の造影 CT 写真では，上顎骨前茵部に境界ほぼ明瞭で造影剤によ り淡く不均一に造影される類冈形の充実性病変を認め，唇 側皮質骨は大きく欠損していた（写真 2B），鼻腔底には濃 染像は認めなかった。 また，骨シンチ・ ${ }^{67} \mathrm{Ga}$ シンチグラフ イなどからは全身的に異常集積を認めなかった。

臨床診断：上顎骨良性腫瘍の疑い.

処置および経過：2003 年 5 月曰日，全身麻酔下にて腫 瘍切除術を施行した. $3+3$ 唇側菌肉部に切開を加え, 粘 膜骨膜弁を剥離したところ，唇側皮質骨は大きく欠損し， 線維性被膜によって, 一部不完全に被包され, 硬結を伴っ た腫瘤を認めた。ささに病変部の剥離をすすめると，上顎 骨口蓋部にも骨欠損を認め，口蓋粘膜との癒着を認めた. 病変を一塊として摘出し, 術中迅速病理診断を行ったとこ ろ，唾液腺悪性腫瘍と診断されたため，さらに周囲の骨に 追加切除を加えた後, 開放創として硫酸ジベカシン軟高ガ 一ゼを挿入して終了とした。術後，追加治療として術後 7 日目から 19 日目までに化学療法：TS-1 (100mg/分 2) を 内服投与，術後 22 日目から 52 日目までに化学療法 (CBDCA 250mg, PEP 20mg) と放射線治療（外部照射，X 線，2Gy/day，total 40Gy）の同時併用療法を施行した。 そ の後, 経過良好にて術後 66 日目に退院となり, 再度, 術後 77 日目から 105 日目までTS-1（100mg/分 2) を内服投与 した. 創部は次第に正常粘膜にて覆われ, 柬槽骨と柬が温 存されたことで審美的・機能的に良好な状態を維持してい る. その後, positron emission tomography（PET）検查を 


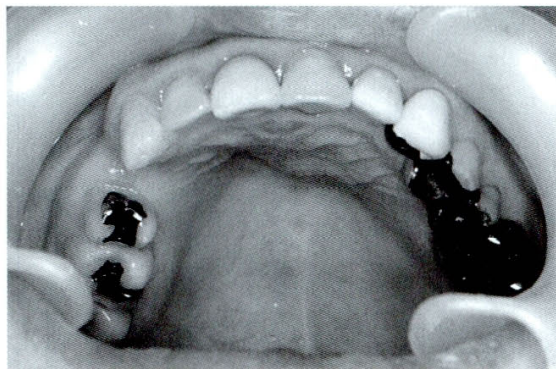

写真 1 初診時口腔内写真 $1+3$ 口蓋側菌肉部に，境界明睹， 弾性硬，丘状の腫脹を認めた。
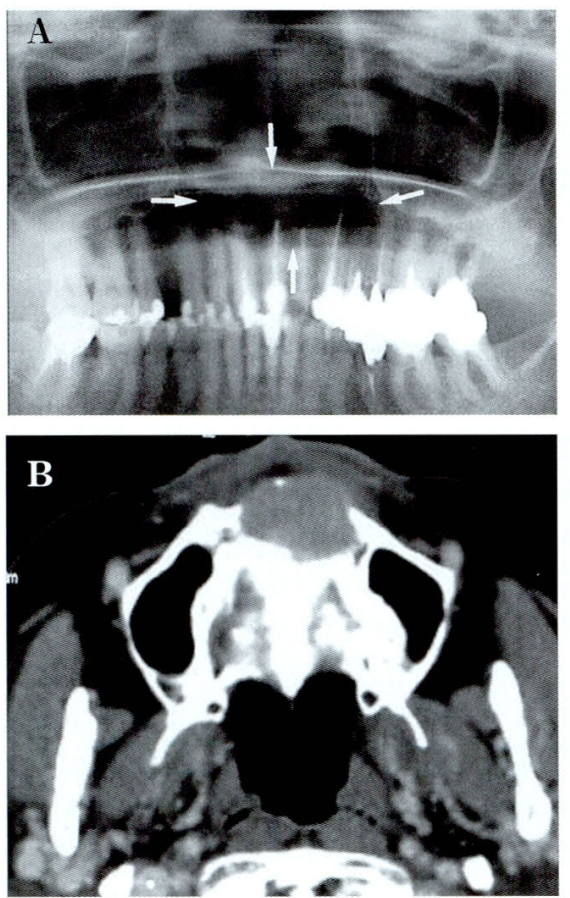

写真 2 パノラマX線写真打よび CT 写真

パノラマX線写真では, $2+3$ 部の 境界明睹な骨透過像を認めた (知印)

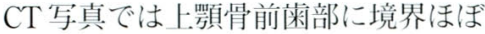
明睹な類円形の充実性病変を認めた。
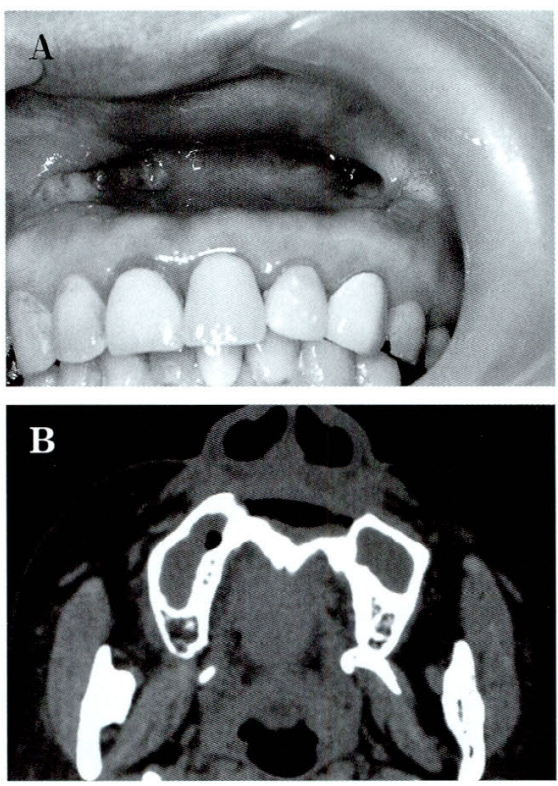

写真 3 術後写真 A : 口腔内写真 B ：CT写真 再発を疑わせる所見を認めない。

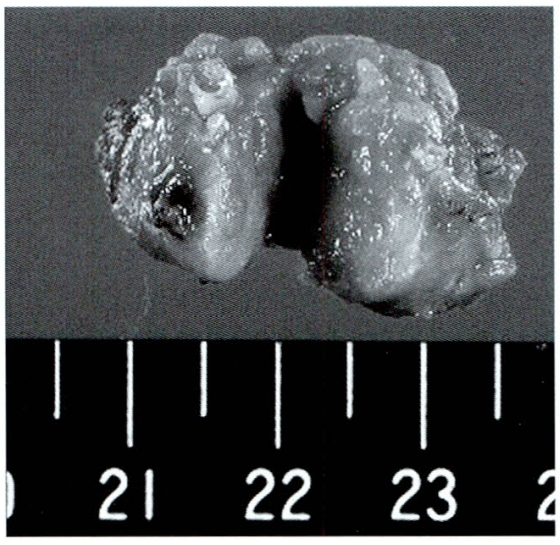

写真 4 摘出標本写真（割面）

腫瘤は20×20 $2018 \mathrm{~mm}$ 大で゙，表面に は小腫瘤を伴い被膜は不完全であった。 割面は均一な灰白色，充実性であった。
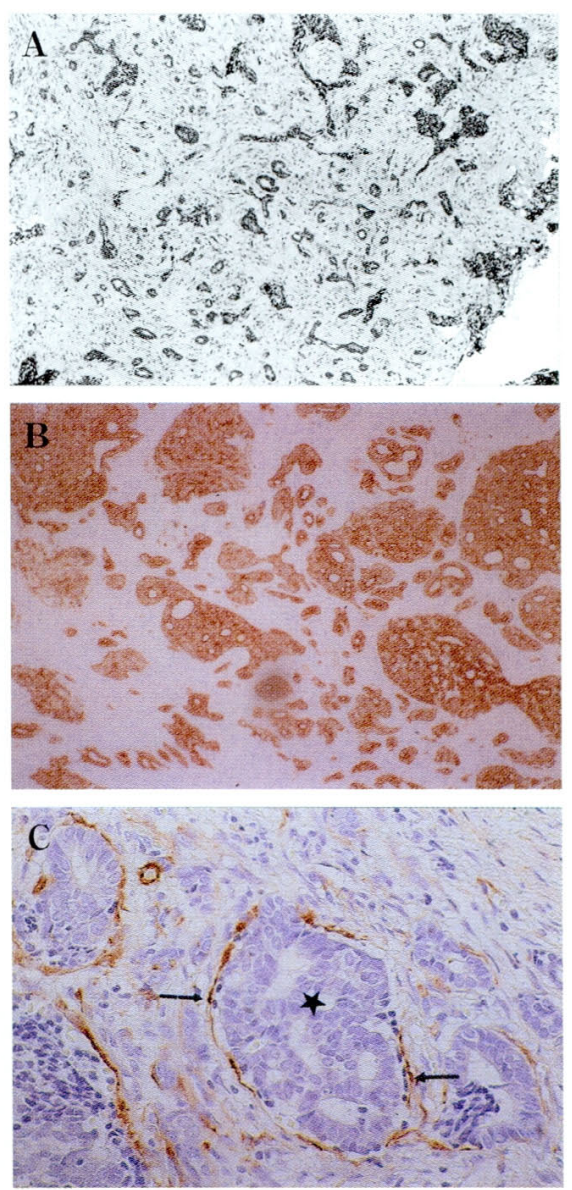

写真 5 病理組織像

A：核の濃染する異型細胞が小充実 性，管状あるいは篩状の胞巣を 形成し浸潤性に增生を認めた (H-E 染色像, X 40)

B ：腫瘍実質は CK7 に強陽性であっ た (CK7 免疫染色像，× 100)

C : 丸は腫瘍実質を示し, $\alpha$-SMA にて腫瘍実質を取り囲む筋上 皮細胞（矢印）に陽性所見存 認めた（ $\alpha$-SMA 免疫染色像, $\times 400)$.
行うなど㛜重な経過観察を継続し, 術後 1 年半以上経過し ているが新たな再発，転移は認めら机ていない（写真 $3 \mathrm{~A}$, $3 \mathrm{~B})$.

摘出標本所見：大きさ $20 \times 20 \times 18 \mathrm{~mm}$ の腫瘤で，割面 は均一な死白色，充実性であった。辺縁部に小腫瘤を伴い， 表面の線維性被膜は一部で欠損していた（写真 4).

病理組織学的所見：核の濃染する異型細胞が小充実性, 管状あるいは篩状の胞巣を形成し浸潤性に増生老認めた。 腫瘍は一部被膜内に浸潤像を認め, 間質には線維組織の増 生が著明であった。多糖類染色（PAS 染色）では，陰性で 粘液産生細胞を特定できなかった。また，免疫組織化学的 染色では，サイトケラチン (cytokeratin, CK) 7 (+), CK 高分子 $(+), \alpha$-平滑筋アクチン $(\alpha$-smooth muscle actin,
$\alpha$-SMA) (+), CK20 (一), 胎児性癌関連抗原（carcinoembryonic antigen, CEA) (-), S-100 蛋白 (一) であ り，腫瘍実質にCK7, CK 高分子に強い陽性所見を認めた。 また，腺房 (分泌部) と導管 (介在部) を取り囲む筋上皮 細胞に $\alpha$-SMA 陽性所見を認めた（写真 5A，5B，5C）。

病理組織学的診断: 腺癌 (NOS).

$$
\text { 考察 }
$$

唾液腺腫瘍の大多数は腺実質組織に由来する上皮性腫瘍 である ${ }^{3)}$ 。また，唾液腺腫瘍は頭頸部領域における腫瘍の 約 $5 \%$ 前瑷を占め, 一般に耳下腺に好発するが，口腔外科領 域では小哢液腺由来のものが多数を占める傾向にある4）。 また，䪽骨中心性に発生する喠液腺腫瘍は，小喠液腺腫瘍 


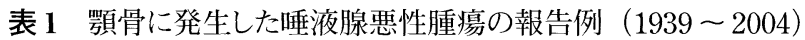

\begin{tabular}{|c|c|c|c|}
\hline 報告例 & 報 告 者 & 発生部位 & 病理組織学的診断 \\
\hline 1 & Lepp 10) & 下顎骨 & 粘表皮癌 \\
\hline 2 & Sonesson ${ }^{11)}$ & 下顎骨 & 粘表皮癌 \\
\hline 3 & Hertz ${ }^{12)}$ & 下顎骨 & 粘表皮癌 \\
\hline 4 & Bumsted ${ }^{13)}$ & 下顎骨（前方部） & 腺様囊胞癌 \\
\hline 5 & Szerlip 14) & 下顎骨（前方部） & 粘表皮癌 \\
\hline 6 & Tarnai ${ }^{15)}$ & 下嚬骨 & 粘表皮癌 \\
\hline 7 & Chaudhry 5 16) & 上顎骨 & 粘表皮癌 \\
\hline 8 & Rhymes $ら$ 17) & 上顎骨 & 粘表皮癌 \\
\hline \multirow[t]{2}{*}{9} & Bhaskar 18) & 下顎骨（煩側面） & 粘表皮癌 \\
\hline & & 下顎骨 & 粘表皮癌 \\
\hline 10 & Rzucidlo 5 19) & 下顎骨 & 粘表皮癌 \\
\hline 11 & Attenson 5 20) & 下顎骨 & 粘表皮癌 \\
\hline 12 & Lacour 5 21) & 下顎骨 & 粘表皮癌 \\
\hline 13 & Brown $\zeta^{22)}$ & 下顎骨 & 粘表皮癌 \\
\hline 14 & Weinstein $ら^{23)}$ & 上顎骨 & 粘表皮癌 \\
\hline 15 & Silverglade $\zeta^{24)}$ & 下顎骨 & 粘表皮癌 \\
\hline \multirow[t]{2}{*}{16} & Smith 5 25) & 上顎骨（ 6 例） & 粘表皮癌 \\
\hline & & 下顎骨（ 3 例） & 粘表皮癌 \\
\hline 17 & Schultz ら 26) & 下顎骨 & 粘表皮癌 \\
\hline \multirow[t]{4}{*}{18} & Dhawan 527$)$ & 下顎骨 & 腺様囊胞癌 \\
\hline & & 上顎骨（ 3 例） & 腺様囊胞癌 \\
\hline & & 上顎骨（2 例） & 粘表皮癌 \\
\hline & & 下顎骨 & 粘表皮癌 \\
\hline \multirow[t]{5}{*}{19} & Brookstone 5 1) & 下頶骨（７例） & 粘表皮癌 \\
\hline & & 下顎骨（2 例） & 腺様囊胞癌 \\
\hline & & 下顎骨 & 腺癌（NOS） \\
\hline & & 上顎骨 & 粘表皮癌 \\
\hline & & 下顎骨（2 例） & 腺癌（NOS） \\
\hline 20 & 自験例 & 上顎骨 & 腺癌（NOS） \\
\hline
\end{tabular}

のうちの $2.6 \%$ 占めると報告されている ${ }^{5)}$.

唾液腺腫瘍の病理組織学的分類として AFIP (Armed Forces Institute of Pathology）分類第 3 版では，いずれに も分類されない腺癌のみを腺癌（NOS）として抢り，除外 診断的に用いられている。 その頻度に関しては粘表皮癌に 次いで頻度の高い組織型として説明されており ${ }^{2)}$, 腺癌の 細分化がなされてもな㟫癌（NOS）が多数あることは唾 液腺腫瘍の分類の困難さを物語っている。その理由として, 唾液腺組織は他部の腺組織に比べて組織構造が複雑多様で あり，腫瘍組織ではさまざまな形態修復を伴い，多様な分 化を示す腺上皮細胞と筋上皮細胞が，組織構築にかかわる ことが挙げられる ${ }^{6)}$.

顎骨内に生じる喠液腺悪性腫瘍を腺様囊胞癌や腺癌 （NOS）などの筋上皮細胞を含む喠液腺悪性上皮性腫瘍と 筋上皮細胞を認めない粘表皮癌に大別して，発生起源につ いて文献的考察を加えて述べる。まず，骨内に生じる腺 様囊胞癌, 腺癌 (NOS) の発生起源については，発症がき わめてまれであるため，それを考察した論文は少ない. Bouquot ら ${ }^{5 ）}$ は異所性に生じる小唾液腺は菌原性組織の 発生の影響を受けるとしており，㐘堤が発生早期において 小唾液腺組織を骨内に誘導し，小唾液腺を骨中心性に生じ
させると仮定し，小唾液腺が顎骨内に存在する確率は $0.3 \%$ と報告している，このように，本腫瘍は何らかの要因 で異所性に顎骨内に生じた小唾液腺が悪性化したものと考 えられる ${ }^{1,5)}$.

次に顎骨に発生する粘表皮癌については，多くの文献で 議論されており，菌原性囊胞の蓑層上皮，異所性腺組織， 封入された臼後腺などの由来があるとされる $\left.{ }^{1,5}, 7\right)$. その 中でも唾液腺由来よりも菌原性組織由来である場合の方が 多いとされており, Eversole ら ${ }^{7)}$ は顎骨内に生じた約半数 の粘表皮癌は先駆的に同部に含茵性囊胞などの菌原性囊胞 や埋伏柬があり，それらと関連していると報告している， 病理組織学的に, Brookstone $5^{1)}$ は柬原性囊胞の裹層上 皮に粘液産生細胞を認めるとして，それぞれ含蒾性囊胞 $(42 \%)$, 柬根囊胞 $(39.6 \%)$, 柬周囊胞 $(20 \%)$, 柬原性角 化囊胞 $(3.7 \%)$ に粘液産生細胞が含まれると報告した. その粘液産生細胞が悪性化した場合に粘表皮癌が発生する と考えられ，菌原性囊胞の被覆上皮や菌原性上皮遺残が粘 表皮癌の由来とされる。また，棞の発生期より粘液産生細 胞は認めても，筋上皮細胞を含む腺組織構造はもたず，柬 原性由来の腺様囊胞癌や腺癌（NOS）は報告されていない.

次に，上顎骨に発生した唾液腺悪性腫瘍は下靧骨に発生 した場合と比べて発生部位，起源が特定しにくいとされて いる ${ }^{8)}$ 。これは上顎骨に打いては上顎洞や鼻腔が隣接して おり，その腺組織由来の腺癌が発生する可能性があるため である ${ }^{8)}$. また, Miller $5^{9)}$ は切蒾管，鼻口蓋管囊胞のう ち $31 \%$ に打いて粘液腺が含まれていることを指摘し，同 部より唾液腺悪性腫瘍が生じる可能性も挙げている.

われわれが文献を渉猟した限りにおいて，本症例を含め て顓骨中心性に発生した喠液腺悪性腫瘍は，上顎が 16 例， 下顎骨が 31 例で上顎は下顎に比べて少なく，その病理組 織学的分類では粘表皮癌が大半 $(76.6 \%)$ を占め，次いで， 腺様囊胞癌 $(14.9 \%)$, 腺癌 (NOS) $(8.5 \%)$ の順であっ た。なかでも，上顎骨中心性に発生した腺癌（NOS）は本 症例のみであった（表 1)。なぜ上顎骨に比べて下顎骨に発 生しやすく，かつ下顎骨後方部が好発部位になるのかにつ いての詳細は不明であるが，下顎孔と臼後腺が近いことか

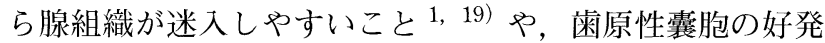
部位は下顎臼柬部から下䯪枝部であることを考慮すると， 柬原性囊胞由来の粘表皮癌が同部に多く発生しやすいので はないかと考えられる.

上頢骨内腺癌についての発生起源は，1）異所性に上顎 骨内に存在した小唾液腺，2）上顎骨に隣接する口蓋腺の 小唾液腺，3）上顓洞や鼻腔の腺組織，4）切菌管や鼻口 蓋囊胞を由来とする腺組織，5）㐘原性囊胞の裏層上皮の 粘液腺組織の 5 つが考えられる.

1）については，全身の腺組織に筋上皮細胞を含むもの

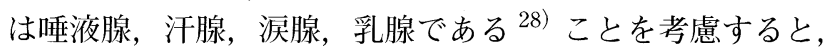
病理組織像に腺房や腺管を囲む $\alpha$-SMA 陽性の筋上皮細胞 が認められたことから, 本症例の本態は唾液腺由来である 可能性が高い. 2) については, 術中所見にて上䫈骨口蓋部 が久損し一部口蓋粘膜と連続していたことから，口蓋腺が 形質転換し，骨内に浸潤した可能性も挙げられるが，口蓋 腺の通常の分布領域よりも腺癌（NOS）がかなり前方に発 
生していること，上顎骨口蓋部より頓側皮質骨の欠損を大 きく認めたことから，通常の口蓋粘膜に分布する口蓋腺由 来と断定するには疑問の余地がある．3）については，術中 所見より上顎洞や鼻腔粘膜に病変が接さず，癒着など認め なかったため，同部が発生起源であるとは考えにくい，4） については，鼻口蓋囊胞の $31 \%$ に粘液腺を認めたとされ ているが ${ }^{8)}$ 発生報告例はない，5）については，歯原性囊 胞の裏層上皮に扁平上皮細胞，粘液産生細胞や中間細胞を 認めるが，筋上皮細胞や唾液腺特有の腺組織構造を認めな いため, 腺様囊胞癌や腺癌（NOS）になる可能性は低いと 思われる. しかし，一方では高い割合で埋伏茵に隣接して 腺癌（NOS）を認めることや蒾堤の上皮性細胞は分化能が 高く, 異なった細胞に分化する可能性も挙げられている ${ }^{5)}$.

上記のことから推察すると，1）の小喠液腺が何らかの 要因で異所性に上顎骨内に迷入した上で形質転換し，上顎 骨中心性に生じた腺癌（NOS）である可能性が高いと思わ れるが，4），5）の発生起源も完全には否定できない.

腺癌（NOS）については，速やかな浸潤性発育とともに， 転移を形成する高覀性度のものから，緩慢な発育で転移を 形成しない比較的良好な経過をたどる悪性度の低いものが 報告されている。.また，粘表皮癌は被膜を形成せず，比較 的良好な経過をたどることが多いとされ，とくに小喠液腺 由来で顎骨中心性であるものは予後が良いとされている ${ }^{3)}$. 今回の症例においては，腫脹を自覚してから当院で加療す るまでの期間が， 5 か月とやや長いにもかかわらず病変部 の著明な変化がなかったことや，被膜を一部認めたこと， 転移や隣接臟器への浸潤が認められなかったことなどか ら, 腺癌 (NOS) の中でも比較的悪性度の低いものと考え られる。しかし，本症例のように，顎骨内に発生した腺癌 （NOS）に対して推奖される治療法や予後については，統 一した見解がないため，厳重な経過観察とともに多施設間 での症例の収集および臨床統計的検討が望まれる.

謝辞

稿を終えるにあたり，懇切なるご指導を賜りました本学医学 部附属病院病理部湊 宏助教授に深遠なる感謝の意を捧げます.

\section{引 用 文 献}

1) Brookstone, M.S., Huvos, A.G., et al.: Central salivary gland tumors of the maxilla and mandible: a clinicopathologic study of 11 cases with an analysis of the literature. J Oral Maxillofac Surg 50: 229-236 1992.

2）森永正二郎：唾液腺腫瘍の病理組織分類. 病理と臨 床 20: $10-162002$.

3）石川梧郎監修：口腔病理学. 改定版, 永末書店, 京都, 1970, 716-775 頁.

4）山中康嗣，桐田忠昭，他：唾液腺腫瘍 90 例の臨床統 計的検討. 口腔腫揚 11: 1-10 1999 .

5) Bouquot, J.E., Gnepp, D.R., et al.: Intraosseous salivary tissue: jawbone examples of choristomas, hamartomas, embryonic rests, and inflammatory entrapment. Oral Surg Oral Med Oral Pathol 90: 205-217 2000.

6) 二階宏昌, 岡邊治男, 他 : 菌学生のための病理学一口 腔病理編. 第 1版，医茵薬出版，東京，1989，252-265 頁.
7) Eversole, L.R., Sabes, W.R., et al.: Aggressive growth and neoplastic potential of odontogenic cysts. Cancer 35: 270-282 1975

8) Waldron, C.A. and Koh, M.L.: Central mucoepidermoid carcinoma of the jaws: report of four cases with analysis of the literature and discussion of the relationship to mucoepidermoid, sialodontogenic, and glandular odontogenic cysts. J Oral Maxillofac Surg 48: 8718771990.

9) Miller, A.S. and Winnick, W.: Salivary gland inclusion in the anterior mandible: report of a case with a review of the literature on aberrant salivary gland tissue and neoplasms. Oral Surg 31: 790-797 1971.

10) Lepp, H.: Zur Kenntnis des papillär wachsenden schleimigen Cystadenokarzinoms der Mundhöhle. Beitr Path Anat 102: 164-186 1939.

11) Sonesson, A.: Intra-osseous mucus-secreting and cystic epidermoid carcinoma of the jaw. Acta Radiol 34: 25-32 1950.

12) Hertz, J.: Mucus-secreting tumours of the jaws. Acta Chir Scand 103: 277-292 1952.

13) Bumsted, W.D.: Cylindroma of the mandible. Oral Surg 8: 546-555 1955.

14) Szerlip, L.: Cystic mucoepidermoid carcinoma: report of a case. Oral Surg 9: 584-588 1956.

15) Tarnai, C.: Mucoepidermoid tumor of the mandible: exarticulation of tumor and insertion of metal prosthesis. Amer J Surg 92: 872-876 1956.

16) Chaudhry, A.P., Deloph, T.H., Jr., et al.: Mucoepidermoid tumor arising from ectopic minor salivary glands in the maxilla: report of a case. J Oral Surg 19: 521-523 1961.

17) Rhymes, R., Jr. and Hardin, J.C., Jr.: Mucoepidermoid carcinoma: report of a case. J Oral Surg 21: 239-242 1963.

18) Bhaskar, S.N.: Central mucoepidermoid tumors of the mandible. Cancer 16: 721-726 1963.

19) Rzucidlo, Zb. and Rzeszotko-Adamiczka, D.: Über einen Mukoepidermoidtumor eines Unterkiefers. $Z$ Allg Path 105: 409-412 1964.

20) Attenson, M., Kaufman, M., et al.: Mucoepidermoid carcinoma of the mandible: report of a case. J Oral Surg 22: 350-354 1964

21) Lacour, M., Reynaud, J., et al.: A case of mucoepidermoid tumor of the mandible. Bull Soc Md Afr Noire Lang Franc 11: 73-77 1966.

22) Brown, A.M. and Lucchesi, F.: Central mucoepidermoid tumor of the mandible: report of a case. J Oral Surg 24: 356-364 1966.

23) Weinstein, I.R. and Nagai, I., et al.: Mucoepidermoid tumor of the maxilla: report of a case. Oral Surg 23: 1111967.

24) Silverglade, L.B., Alvares, O.F., et al.: Central mucoepidermoid tumors of the jaws. Cancer 22: 6506531968.

25) Smith, L.R., Dahlin, D.C., et al.: Mucoepidermoid carcinomas of the jawbones. J Oral Surg 26: 387-393 1968.

26) Schultz, W. and Whitten, J.B., Jr.: Mucoepidermoid carcinoma in the mandible: report of a case. J Oral Surg 27: 337-340 1969.

27) Dhawan, I.K., Bhargava, S., et al.: Central salivary gland tumors of the jaws. Cancer 26: 211-217 1970.

28) Eroschenko, V.P.: Di Fiore 人体組織困譜. 第 9 版, 南江堂, 東京, 2003, 1-364 頁. 